\title{
Pesticide Accumulation in Turkey's Meriç River Basinwater and Sediment
}

\author{
Cem Tokatlı ${ }^{*}$, Esengül Köse², Arzu Çiçek ${ }^{3}$, Özgür Emiroğlu ${ }^{4}$ \\ ${ }^{1}$ Trakya University, İpsala Vocational School, Department of Laboratory Technology, İpsala/Edirne, Turkey \\ ${ }^{2}$ Eskişehir Osmangazi University, Department of Environmental Protection and Control, Eskişehir, Turkey \\ ${ }^{3}$ Anadolu University, Applied Environmental Research Centre, Eskişehir, Turkey \\ ${ }^{4}$ Eskişehir Osmangazi University, Department of Biology, Eskişehir, Turkey
}

Received: 9 April 2018

Accepted: 15 December 2018

\begin{abstract}
The Meriç River is located in the Thrace Region of Turkey, which has great importance in terms of agricultural potential and is known as "Rice Land". The Meriç is also the longest river in the Balkans and is known to be exposed to intensive pollution by means of special agricultural pressure on the system. The aim of this study was to determine pesticide accumulation in water and sediment of the Meriç River Basin. For this purpose, water and sediment samples were collected in spring (rainy) of 2017 from 24 stations selected on the basin and pesticide contents. A total of 174 different pesticide varieties were investigated in water and sediment samples using liquid chromatograph mass spectrometry LC/MS. According to detected data, the concentration of pesticide residues ranged from $30.4 \mathrm{ng} / \mathrm{L}$ (thiabendazole in Meriç River) to $291,310 \mathrm{ng} / \mathrm{L}$ (carbendazim in Ergene River) for water samples, and from $12.4 \mathrm{ng} / \mathrm{L}$ (spiroxamine in Gala Leke) to 15,947 (carbendazim in Ergene River) for sediment samples. There was a clear dominance of the carbendazim in all the investigated aquatic habitats. It was also determined that pesticide concentrations detected in the Meriç River Basin, especially in the Ergene River, were found to be at quite high levels and the system has Class III-IV water quality in terms of total pesticide accumulation.
\end{abstract}

Keywords: Meriç River Basin, Balkans, water, sediment, pesticides

\section{Introduction}

Aquatic ecosystem quality around the globe is decreasing daily because of the rapid growth of the world's population and the development of industry. Pesticides are a widespread group of chemical substances used to improve agricultural production

*e-mail: tokatlicem@gmail.com and they have become an integral part of society and are being used for diverse activities ranging from crop protection from insect pests, weeds, rodents, and fungal diseases to animal husbandry and public health applications. However, they are hazardous for living organisms, human and environmental health, even at low concentrations, and can reach fish, birds and humans by means of the food chain. Their toxicity and long persistence in the environment has raised global concern [1-3]. 
Table 1. Coordinate information of selected stations.

\begin{tabular}{|c|c|c|c|c|c|c|c|}
\hline \multicolumn{2}{|c|}{ Stations } & North & East & \multicolumn{2}{|c|}{ Stations } & North & East \\
\hline \multirow{5}{*}{$\begin{array}{l}\text { Gala } \\
\text { Lake }\end{array}$} & GL1 & 40.78189 & 26.21059 & \multirow{7}{*}{$\begin{array}{l}\text { Meriç } \\
\text { River }\end{array}$} & M1 & 41.66233 & 26.55130 \\
\hline & GL2 & 40.78089 & 26.19306 & & M2 & 41.63857 & 26.57971 \\
\hline & GL3 & 70.77093 & 26.18911 & & M3 & 41.40480 & 26.63160 \\
\hline & GL4 & 40.76386 & 26.16486 & & M4 & 41.13640 & 26.48129 \\
\hline & GL5 & 40.75516 & 26.17714 & & M5 & 40.94286 & 26.33319 \\
\hline \multirow{5}{*}{$\begin{array}{c}\text { Siğırc1 } \\
\text { Lake }\end{array}$} & SL1 & 40.84322 & 26.32872 & & M6 & 40.86219 & 26.23841 \\
\hline & SL2 & 40.84114 & 26.34372 & & M7 & 40.73987 & 26.11582 \\
\hline & SL3 & 40.82173 & 26.32836 & \multirow{2}{*}{$\begin{array}{c}\text { Sazlidere } \\
\text { Stream }\end{array}$} & SD1 & 41.61810 & 26.67925 \\
\hline & SL4 & 40.82173 & 26.30954 & & SD2 & 41.45525 & 26.61781 \\
\hline & SL5 & 40.81802 & 26.32438 & \multirow{3}{*}{$\begin{array}{l}\text { Ergene } \\
\text { River }\end{array}$} & E1 & 41.28431 & 26.69829 \\
\hline \multirow{2}{*}{$\begin{array}{l}\text { Tunca } \\
\text { River }\end{array}$} & $\mathrm{T} 1$ & 41.83295 & 26.58769 & & E2 & 41.13641 & 26.48129 \\
\hline & $\mathrm{T} 2$ & 41.66759 & 26.55344 & & E3 & 41.06200 & 26.36463 \\
\hline
\end{tabular}

The Meriç River, which is the longest river in the Balkans, is known as the lifeblood of the Thrace Region of Turkey. The Tunca and Ergene rivers are the main branches of the Meriç. Gala and Sığırcı lakes are the most important lentic parts of the system. They are located on the Meriç Delta, where is formed on about 45,000 ha area at the mouth of the Meriç and is listed as Class A of International Wetlands. The Meric Delta is very rich in terms of biological resources and can

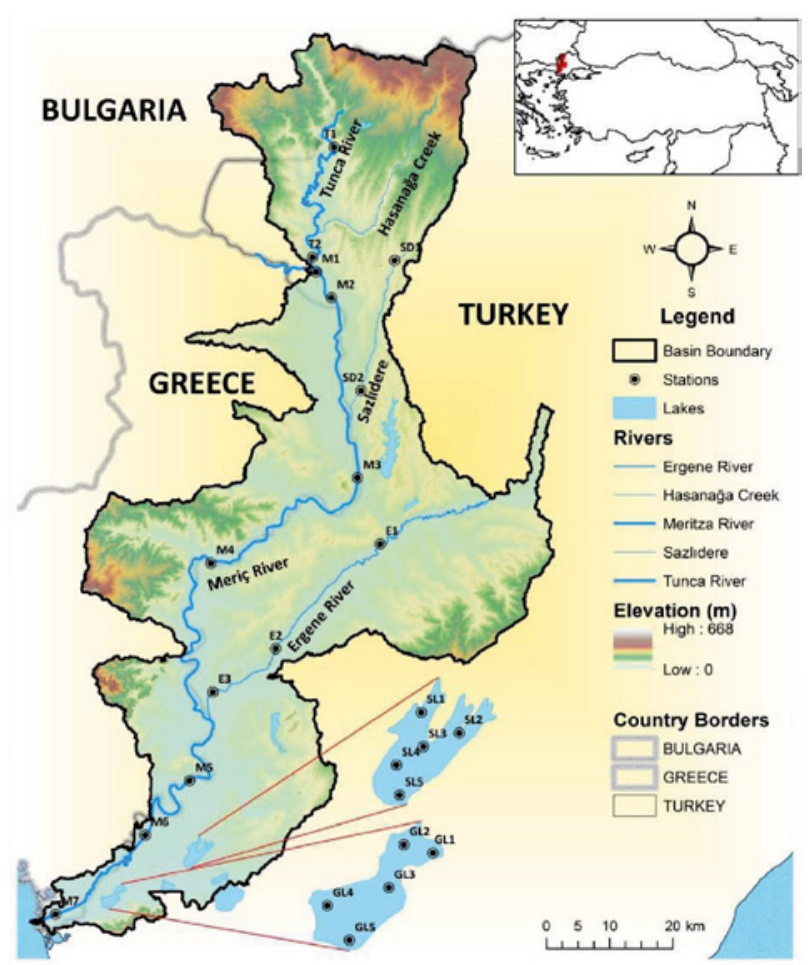

Fig. 1. Topographic map of Meriç River Basin and selected stations. be classified as an internationally important wetland because of its location along a bird migration route. This significant basin is being exposed to intensive organic and inorganic pollution by means of agricultural applications. Over the last few decades, the aquatic ecosystems located in the Meriç River Basin have been significantly contaminated by persistent pollutant of agricultural origin; because of monoculture practices, mainly rice cultivation is conducted around the region. It is reported that about $25 \%$ of total rice production of Turkey is being supplied from this basin. Industrial activities conducted around the Ergene River, once known as one of the most polluted lotic habitats of Turkey, are also one of the main contamination sources of the system [4-6].

The main objective of this study were to identify and quantify pesticide residues in water and sediment samples and to evaluate the toxicological significance of the investigated contamination in the aquatic components of the Meriç River Basin (Gala and Sığırcı lakes and Tunca, Ergene and Meriç rivers).

\section{Material and Methods}

\section{Study Area and Collection of Samples}

Samples were collected from the middle of the rivers (over the bridges on the rivers) in spring (rainy) season of 2017, when the precipitation and surface runoff have increased significantly in the region. After a preliminary field study, 24 stations were selected on the Meriç River Basin considering the main basin components and pollution sources. Two of the stations were located on the Tunca River, 3 of the stations were located on the Ergene River, 7 of the stations were located on the Meriç River, 2 of the stations were located on Sazlıdere 
Stream, 5 of the stations were located on Gala Lake and 5 of the stations were located on Siğırc1 Lake. Coordinate information is given in Table 1 and a map of study area is given in Fig. 1 .

Water samples were collected $0.5 \mathrm{~m}$ below the water surface in $1 \mathrm{~L}$ pre-cleaned glass bottles and kept at $4^{\circ} \mathrm{C}$ until chemical analysis. Sediment samples were collected from the upper $10 \mathrm{~cm}$ of sediments with an Ekman grab sampler in $1 \mathrm{~L}$ sterile glass bottles and kept at $4^{\circ} \mathrm{C}$ until chemical analysis. Water and sediment samples were collected.

\section{Pesticide Analysis}

The QUECHERS (quick, easy, cheap, effective, rugged, safe) method has been applied for the extraction of pesticides in the sample and the determination of pesticides has been done using a ZIVAK TANDEM GOLD LC-MS/MS device (the detection limit was 10 ppt) in Trakya University Technology Research and Development Application and Research Center (TÜTAGEM) [7]. The center has an international accreditation certificate within the scope of TS EN/ ISO IEC 17025 issued by TÜRKAK (representative of the World Accreditation Authority in Turkey). The element analyses were recorded as means triplicate measurements.

Regarding the quality control procedures, parameters such as laboratory and field blanks and matrix spikes were evaluated. The reliability of the calibration method and sample preparation was evaluated on the spiked samples. The calibrated midpoints (10000 ppt) were spiked with pesticide-free water, and QUECHERS stages were applied. As a result of the analysis, the recoveries were determined between $80-120 \%$.

\section{Results and Discussion}

The averages of the pesticides detected in water and sediment samples of the lotic and lentic components of the Meriç River Basin are given in Tables 2 and 3. The proportional values of pesticides detected in water and sediment samples and the proportion values of the total pesticide loads recorded in the basin components are given in Fig. 3.

According to the results of this study, pesticide concentrations detected in the Meriç River Basin, especially in the Ergene River, were found to be at quite high levels. From the investigated 174 pesticide varieties in the Meriç River Basin, a total of 13 pesticide varieties were found in water samples and a total of 26 pesticide varieties were found in sediment samples. It has also been found that the most widely used pesticide variety in the region is carbendazim, and the most polluted ecosystem among the investigated aquatic habitatsis the Ergene River. According to the Water Pollution Control Regulation in Turkey, Gala Lake, Sığırcı Lake, Meriç River, Tunca River and Sazlıdere Stream are Class III
Table 2. Mean pesticide values in the waters of basin component stations (ppt).

\begin{tabular}{|c|c|}
\hline Pesticide & Mean \pm SD \\
\hline \multicolumn{2}{|c|}{ Gala Lake (5 stations) } \\
\hline Carbendazim & $3458 \pm 1788$ \\
\hline Thiabendazole & $1479 \pm 21.38$ \\
\hline Forchlorfenuron-706 & $5956 \pm 30.59$ \\
\hline \multicolumn{2}{|c|}{ Sığırcı Lake (5 stations) } \\
\hline Carbendazim & $4271 \pm 1502$ \\
\hline Thiabendazole & $59.80 \pm 9.085$ \\
\hline Thiophonate Methyl & $2021 \pm 490.0$ \\
\hline Forchlorfenuron-706 & $3494 \pm 26.05$ \\
\hline \multicolumn{2}{|c|}{ Meriç River (7 stations) } \\
\hline Propamocarb-hydrochloride & $3726 \pm 3121$ \\
\hline Carbendazim & $11747 \pm 7827$ \\
\hline Thiabendazole & $30.40 \pm 6.885$ \\
\hline Thiamethoxam & $175.0 \pm 168.9$ \\
\hline Thiacloprid & $45.90 \pm 49.76$ \\
\hline Forchlorfenuron-706 & $1515 \pm 1250$ \\
\hline Metalaxyl & $104.5 \pm 30.38$ \\
\hline Cyproconazole & $124.7 \pm 120.1$ \\
\hline Azoxystrobin & $576.6 \pm 560.6$ \\
\hline Dimoxystrobin-688 & $300.7 \pm 281.8$ \\
\hline \multicolumn{2}{|c|}{ Tunca River (2 stations) } \\
\hline Carbendazim & $4042 \pm 774.3$ \\
\hline Thiabendazole & $1518 \pm 56.75$ \\
\hline Forchlorfenuron-706 & $4468 \pm 332.6$ \\
\hline \multicolumn{2}{|c|}{ Sazlidere Stream (2 stations) } \\
\hline Carbendazim & $2944 \pm 1657$ \\
\hline Thiabendazole & $1535 \pm 53.10$ \\
\hline Thiamethoxam & $125.4 \pm 56.13$ \\
\hline Forchlorfenuron-706 & $7009 \pm 44.46$ \\
\hline \multicolumn{2}{|c|}{ Ergene River (3 stations) } \\
\hline Carbendazim & $291310 \pm 285049$ \\
\hline Thiabendazole & $1627 \pm 6.072$ \\
\hline Acetamiprid & $862.7 \pm 359.5$ \\
\hline Forchlorfenuron-706 & $6748 \pm 3167$ \\
\hline Metalaxyl & $833.6 \pm 246.8$ \\
\hline Spiroxamine & $5689 \pm 5057$ \\
\hline
\end{tabular}


Table 3. Mean pesticide values in the sediments of basin component stations (ppt).

\begin{tabular}{|c|c|}
\hline \multicolumn{2}{|l|}{ Sediment } \\
\hline Pesticide & Mean \pm SD \\
\hline \multicolumn{2}{|c|}{ Gala Lake (5 stations) } \\
\hline Carbendazim & $323.7 \pm 92.58$ \\
\hline Forchlorfenuron-706 & $169.7 \pm 311.4$ \\
\hline Spiroxamine & $12.40 \pm 3.412$ \\
\hline Cyproconazole & $57.50 \pm 48.44$ \\
\hline Azoxystrobin & $329.9 \pm 38.17$ \\
\hline Prochloraz & $335.3 \pm 17.80$ \\
\hline Propiconazole & $358.4 \pm 72.99$ \\
\hline Pyriproxyfen & $555.6 \pm 1.591$ \\
\hline \multicolumn{2}{|c|}{ Sığırcı Lake (5 stations) } \\
\hline Carbendazim & $719.3 \pm 455.6$ \\
\hline Thiabendazole & $130.1 \pm 0.936$ \\
\hline Forchlorfenuron-706 & $210.2 \pm 166.7$ \\
\hline Spiroxamine & $13.50 \pm 1.109$ \\
\hline Propiconazole & $272.5 \pm 46.51$ \\
\hline Pyridaben & $737.5 \pm 6.553$ \\
\hline \multicolumn{2}{|c|}{ Meriç River (7 stations) } \\
\hline Propamocarb-hydrochloride & $147.5 \pm 6.739$ \\
\hline Carbendazim & $1056 \pm 621.4$ \\
\hline Thiabendazole & $104.2 \pm 10.16$ \\
\hline Thiamethoxam & $143.6 \pm 183.6$ \\
\hline Acetamiprid & $13.70 \pm 8.351$ \\
\hline Tricyclazole-753 & $11.20 \pm 10.58$ \\
\hline Thiacloprid & $10.60 \pm 10.33$ \\
\hline Flutriafol & $137.3 \pm 145.6$ \\
\hline Forchlorfenuron-706 & $122.5 \pm 68.76$ \\
\hline Metalaxyl & $51.20 \pm 14.51$ \\
\hline Fenproprimorph & $1085 \pm 105.2$ \\
\hline Spiroxamine & $63.60 \pm 65.96$ \\
\hline Azoxystrobin & $413.2 \pm 103.1$ \\
\hline Prochloraz & $788.3 \pm 788.6$ \\
\hline Dimoxystrobin-688 & $197.2 \pm 11.65$ \\
\hline Difenoconazol & $414.3 \pm 95.50$ \\
\hline Pyraclostrobin & $580.1 \pm 3.961$ \\
\hline
\end{tabular}

\begin{tabular}{|c|c|}
\hline Pyriproxyfen & $572.9 \pm 44.42$ \\
\hline Etoxazole & $996.6 \pm 5.220$ \\
\hline \multicolumn{2}{|c|}{ Tunca River (2 stations) } \\
\hline Carbendazim & $196.0 \pm 199.6$ \\
\hline Forchlorfenuron-706 & $523.5 \pm 216.1$ \\
\hline Azoxystrobin & $573.9 \pm 100.6$ \\
\hline Epoxiconazole & $274.2 \pm 52.45$ \\
\hline Prochloraz & $616.0 \pm 123.1$ \\
\hline Rotenone-739 & $6749 \pm 62.47$ \\
\hline Propiconazole & $329.7 \pm 141.8$ \\
\hline Pyridaben & $1727 \pm 2.362$ \\
\hline \multicolumn{2}{|c|}{ Sazlıdere Stream (2 stations) } \\
\hline Carbendazim & $554.2 \pm 632.4$ \\
\hline Forchlorfenuron-706 & $201.8 \pm 130.6$ \\
\hline Azoxystrobin & $629.3 \pm 166.6$ \\
\hline Epoxiconazole & $373.2 \pm 236.1$ \\
\hline Prochloraz & $889.4 \pm 357.5$ \\
\hline Rotenone-739 & $218.8 \pm 154.6$ \\
\hline Propiconazole & $440.0 \pm 256.6$ \\
\hline Pyridaben & $1722 \pm 0.616$ \\
\hline \multicolumn{2}{|c|}{ Ergene River (3 stations) } \\
\hline Methamidophos & $677.4 \pm 744.6$ \\
\hline Carbendazim & $15947 \pm 10328$ \\
\hline Thiabendazole & $140.4 \pm 8.076$ \\
\hline Acetamiprid & $151.5 \pm 129.2$ \\
\hline Thiacloprid & $26.80 \pm 26.99$ \\
\hline Forchlorfenuron-706 & $160.9 \pm 72.94$ \\
\hline Spiroxamine & $30.20 \pm 31.47$ \\
\hline Azoxystrobin & $554.2 \pm 41.32$ \\
\hline Prochloraz & $934.1 \pm 2100$ \\
\hline Propiconazole & $393.3 \pm 191.6$ \\
\hline Difenoconazol & $651.3 \pm 51.98$ \\
\hline Pyriproxyfen & $768.0 \pm 7.452$ \\
\hline Etoxazole & $528.6 \pm 10.83$ \\
\hline Pyridaben & $734.5 \pm 29.25$ \\
\hline
\end{tabular}

water quality, and the Ergene River is Class IV in terms of total pesticide contents [8]. In a study performed in the Meriç Delta, residues of organochlorine pesticides in surface water, sediment, and fish samples were analyzed. In contrast to the results of the present study, it was revealed that the Meriç Delta was declared as low contaminated of organochlorine pesticides and their residues [9]. 

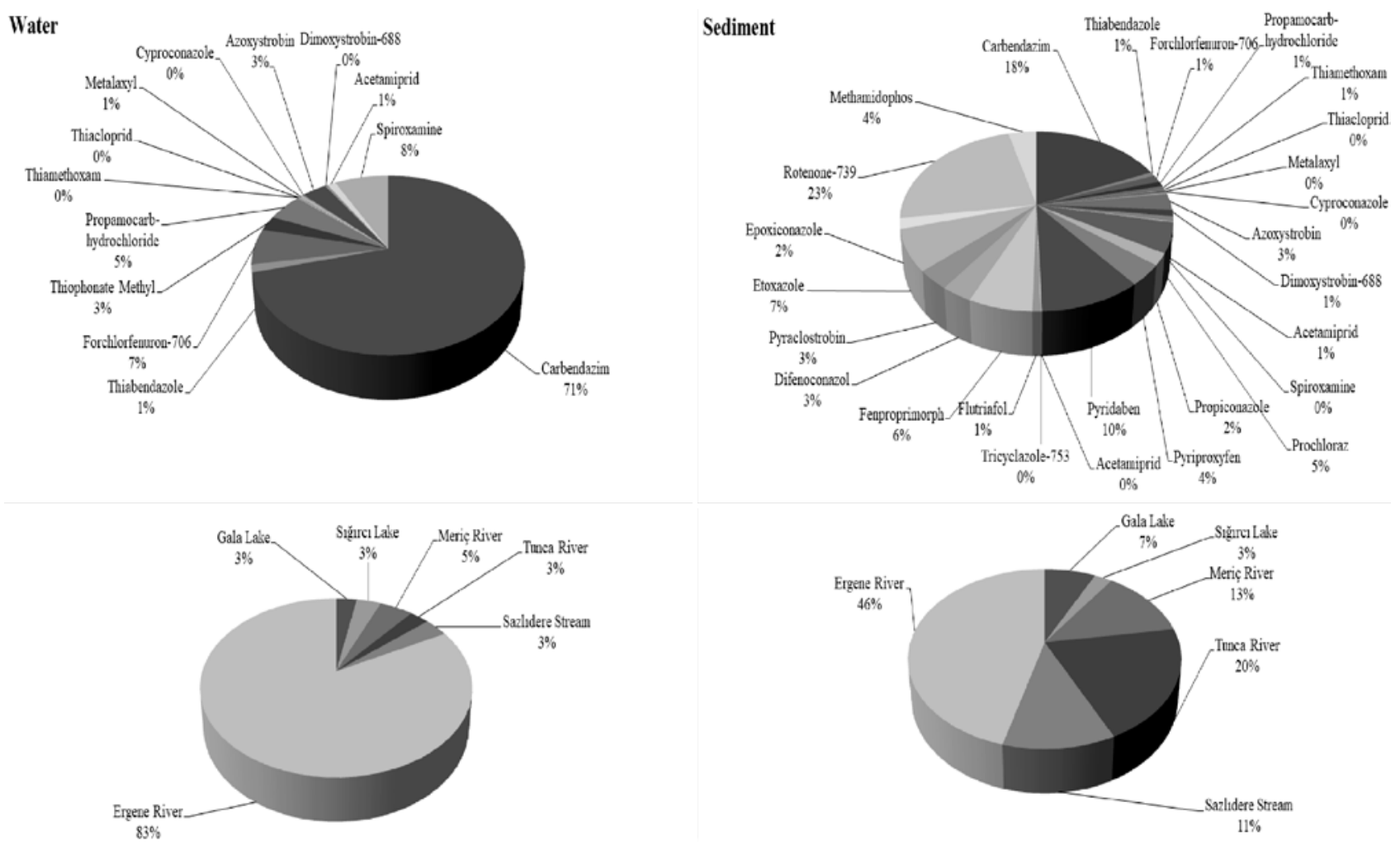

Fig. 2. Pesticide rates (upside) detected in the basin and rates of total pesticide loads (downside) in the basin components.

It was clearly reported that minute concentrations of pesticides are toxic to biological organisms and they threaten ecosystem integrity due to their stable structure and lipophilic character. They also tend to bioconcentrate, bioaccumulate and biomagnify, and are transferred to higher trophic levels through several food chains and may lead to toxicity in non-target organisms like vertebrates and non-vertebrates and even in humans [10-13].

The Meriç River Basin receives many point pollutant inputs like discharge of effluent from factories and industrial wastes by means of especially the Ergene River Basin and non-point inputs like intensive agricultural applications conducted almost all around the basin. In addition to these pollution factors, possible transfer of toxicants from the neighboring countries by means of Meriç and Tunca Rivers could elevate the pesticide contamination in the basin. However, the data of the present study clearly reveals that agricultural runoff is a major pollution source for all the aquatic components of the system and the use of unconscious pesticides in agricultural activities may cause significant health problems on both ecosystem and local people in the near future.

\section{Conclusions}

In the present study, pesticide accumulations in waters and sediments of lotic (Meriç, Ergene and
Tunca Rivers) and lentic (Gala and Sığırcı Lakes) components of the Meriç River Basin were investigated. As a result of this research, the contamination potential of agricultural runoff on the abiotic components of the basin was clearly revealed. The Ergene was found to be the most polluted ecosystem among the aquatic system components, and carbendazim was found to be the most widely used pesticide variety in the Meriç River Basin.

In order to protect the sustainability of this significant aquatic ecosystem, monoculture practices in agricultural activities should be changed and local people should be encouraged to adopt polyculture practices. Also, the use of unconscious chemical fertilizers and pesticides should be avoided by giving the necessary training and environmental awareness for local people.

\section{Acknowledgements}

The authors would like to thank Trakya Universityfor financial and technical support. This investigation was supported by project No. 2016/247 accepted by Trakya University, Commission of Scientific Research Projects.

\section{Conflict of Interest}

The authors declare no conflict of interest. 


\section{References}

1. ZHOU R., ZHU L., YANG K., CHANG Y. Distribution of organochlorine pesticide in surface water and sediment from Qiantang River, East China. Journal of Hazardous Materials, 137, 68, 2006.

2. CHOPRA A.K., SHARMA M.K., CHAMOLI S. Bioaccumulation of organochlorine pesticides in aquatic system - an overview. Environmental Monitoring and Assessment, 173, 905, 2010.

3. CCANCCAPA A., MASIA A., NAVARRO-ORTEGA A., PICO Y., BARCEL D. Pesticides in the Ebro River basin: Occurrence and risk assessment. Environmental Pollution, 211, 41, 2016.

4. TOKATLI C. Drinking water quality of a rice land in Turkey by a statistical and GIS perspective: İpsala District. Polish Journal of Environmental Studies, 23 (6), 2247, 2014.

5. TOKATLI C. Assessment of the water quality in the Meriç River: As an element of the ecosystem in the Thrace Region of Turkey. Polish Journal of Environmental Studies, 24 (5), 2205, 2015.

6. TOKATLI C., BAŞTATLI Y. Trace and toxic element levels in river sediments. Polish Journal of Environmental Studies, 25 (4), 1715, 2016.

7. SCHENCK F.J., HOBBS J.E. Evaluation of the quick, easy, cheap, effective, rugged, and safe (QuEChERS) approach to pesticide residue analysis. Bulletin of Environmental Contamination and Toxicology (New York: Springer), 73 (1), 24, 2004
8. TURKISH REGULATIONS. Yüzeyselsukalitesiyöneti miyönetmeliği, 15 Nisan 2015 tarihliResmiGazete, Say1: 29327, http://suyonetimiormansu.gov.tr, 2015.

9. ERKMEN B., KOLANKAYA D. Determination of organochlorine pesticide residues in water, sediment, and fish samples from the Meriç Delta, Turkey, International Journal of Environmental Analytical Chemistry, 86, 1-2, 161-169, 2006.

10. OGUNFOWOKAN A.O., OYEKUNLE J.A.O., TORTO N., AKANNI M.S. A study on persistent organochlorine pesticide residues in fish tissues and water from an agricultural fish pond. Emirates Journal of Food and Agriculture, 24 (2), 165, 2012.

11. MASIA A., IBANEZ M., BLASCO C., SANCHO J. V., PICO Y., HERNANDEZ F. Combined use of liquid chromatography triple quadrupole mass spectrometry and liquid chromatography quadrupole time-offlight mass spectrometry in systematic screening of pesticides and other contaminants in water samples. AnalyticaChimicaActa, 761, 117, 2013.

12. OGBEIDE O., TONGO I., EZEMONYE L. Risk assessment of agricultural pesticides in water, sediment, and fish from Owan River, Edo State, Nigeria. Environ Monit Assess, 187, 654, 2015.

13. WANG L., JIA H.L., LIU X.J., SUN Y.Q., YANG M., HONG W.J., QI H., LI Y.F. Historical contamination and ecological risk of organochlorine pesticides in sediment core in northeastern Chinese river. Ecotoxicol. Environ. Saf. 93, 112, 2013. 